\title{
Serum Total Triiodothyronine versus Free Tetraiodothyronine and TSH in Patients with HCV Related Cirrhosis and Their Correlation to the Severity of Cirrhosis
}

\author{
Ashraf A. Hammam', Amal A. Jouda2*, Mona E. Hashem ${ }^{3}$ \\ ${ }^{1}$ Internal Medicine Department, Zagazig University, Zagazig, Egypt \\ ${ }^{2}$ Tropical Medicine Department, Zagazig University, Zagazig, Egypt \\ ${ }^{3}$ Clinical Pathology Department, Zagazig University, Zagazig, Egypt \\ Email: *ashraf_hammam2003@yahoo.com,dr.amaljouda@zu.edu.eg,mm_hashem2001@yahoo.com
}

Received 3 February 2016; accepted 11 March 2016; published 14 March 2016

Copyright (C) 2016 by authors and Scientific Research Publishing Inc.

This work is licensed under the Creative Commons Attribution International License (CC BY). http://creativecommons.org/licenses/by/4.0/

c) (i) Open Access

\begin{abstract}
Background and Aim: The levels of thyroid hormones and their binding proteins are altered in patient with cirrhosis. We aim to study the changes in triiodothyronine level in HCV related cirrhosis and its correlation to the severity of liver decompensation. Patients and Methods: This study included seventy two patients with HCV related cirrhosis in three groups Group I: 24 patients with Child A class Group II: 24 patients with Child B and C classes without hepatic encephalopathy Group III: 24 patients with Child B and C classes with hepatic encephalopathy. Results: T3 level was significantly lower in group III than group I and II $(0.74 \mathrm{ng} / \mathrm{ml}$ vs 1 and $1.3 \mathrm{ng} / \mathrm{ml}$ in group II and $I$ in succession). The correlation between Child's score and $\mathrm{T} 3$ level was highly significant $(\mathrm{r}=$ $-0.64, P<0.001)$. Conclusion: Triiodothyronine level is lower in cirrhosis and its level is correlated to the severity of decompensation.
\end{abstract}

\section{Keywords}

Free T4, TSH, Clinical Euthyroid, Cirrhosis, HCV

\section{Introduction}

Cirrhosis is the ninth leading cause of death in the United States and is responsible for $1.2 \%$ of all US deaths;

${ }^{*}$ Corresponding author.

How to cite this paper: Hammam, A.A., Jouda, A.A. and Hashem, M.E. (2016) Serum Total Triiodothyronine versus Free Tetraiodothyronine and TSH in Patients with HCV Related Cirrhosis and Their Correlation to the Severity of Cirrhosis. Open Journal of Gastroenterology, 6, 75-82. http://dx.doi.org/10.4236/ojgas.2016.63010 
about 35,000 deaths each year. Cirrhosis is often preceded by hepatitis and fatty liver (steatosis), independent of the cause. If the cause is treated at this stage, the changes are reversible. The pathological hallmark of cirrhosis is the development of fibrosis that replaces normal parenchyma. Damage to the hepatic parenchyma (due to inflammation) leads to activation of the stellate cell, which increases fibrosis (through production of myofibroblasts) and obstructs blood flow in the circulation [1]. In addition, it secretes TGF- $\beta 1$, which leads to a fibrotic response and proliferation of connective tissue. Furthermore, it secretes TIMP 1 and 2, naturally occurring inhibitors of matrix metalloproteinases, which prevents them from breaking down fibrotic material in the extracellular matrix. The fibrous tissue bands (septa) separate hepatocyte nodules, which eventually replace the entire liver architecture [2].

The thyroid status depends not only on thyroxine secretion but also on normal thyroid hormone metabolism, delivery of $T_{3}$ to nuclear receptors and on receptor distribution and function. Normal thyroid function, which is essential for normal growth, development and the regulation of energy metabolism within cells, is dependent on a normally functioning thyroid and liver axis [3].

The liver performs important functions in the process of thyroid hormone transport and metabolism. The liver extracts $5 \%-10 \%$ of plasma $\mathrm{T}_{4}$ during a single passage, as shown by studies using $\left[\mathrm{I}^{131}\right] \mathrm{T}_{4}[4]$. The liver also synthesizes a number of plasma proteins that bind the lipophilic thyroid hormones. More than ninety nine percent of the thyroid hormones are bound to thyroxine-binding globulin, thyroxine-binding prealbumin and albumin in plasma. This bound portion of the hormone works like a large reservoir of free circulating hormone. The free hormone component within plasma is in equilibrium with the protein-bound hormone, and it is this free fraction which accounts for the hormone's biological activities. The plasma concentrations of free $T_{4}$ and $T_{3}$ are at a steady concentration, so that the tissues are exposed to the same concentrations of the free hormone [5].

There are evidences showing an association between chronic liver diseases and changes in thyroid gland. Furthermore, it is demonstrated that levels of thyroid hormones and their binding proteins are altered in patient with hepatic disorders, especially cirrhosis [6]. Some studies even say that there's a significant increase in thyroid glandular volume in cirrhotic patients when compared with controls. However, almost all of them are clinically euthyroid [7].

On the other hand, some authors believe that the changes in thyroid hormones levels may be regarded as an adaptive hypothyroid state that helps to decrease the basal metabolic rate within hepatocytes and preserve liver function and total body protein stores [8]. This hypothesis is based on a study in cirrhotic patients which showed that the onset of hypothyroidism due to intrinsic thyroid disease during cirrhosis resulted in a biochemical improvement in liver function as compared to cirrhotic controls [9]. Hypothyroidism has also been associated with lesser degrees of decompensation in cirrhosis [10].

Egypt has the highest prevalence of hepatitis C virus (HCV) in the world it is estimated that about $15 \%$ of population are infected with hepatitis C. About $85 \%$ of patients infected with HCV develop chronic hepatitis C (CHC) and are at risk for fibrosis progression. About 20\% - 30\% of CHC patients will develop cirrhosis of the liver within years. Once cirrhosis is established the rate of HCC development is $1 \%$ - $4 \%$ per year [11]. Being a major health problem in Egypt, and due to its role in development of cirrhosis we chose post-HCV cirrhosis to evaluate the relation between thyroid functions and liver disease.

\section{Aim of the Work}

This study aims at exploring the changes in thyroid functions in patients with HCV related cirrhosis and the correlation between them and the severity of liver dysfunction.

\section{Patients and Methods}

This study had been carried out in Zagazig University Hospitals in the period between August 2014 and August 2015. The study design was approved by the Institutional Review Board (IRB) of Faculty of Medicine, Zagazig University. The study included 72 patients with liver cirrhosis due to chronic HCV infection, 40 males and 32 females and their ages ranged from 40 to 70 years old.

\subsection{Inclusion Criteria}

Patients with liver cirrhosis diagnosed by combination of clinical, ultrasonic and laboratory assessments due to chronic HCV hepatitis diagnosed by positive anti-HCVAb and PCR. 


\subsection{Exclusion Criteria}

- Patients $<18$ and $>60$ years old

- Patients who refused to give written consent to be included in the study (the consent included description of the study and subsequent editing and publication)

- Patients suffering from previously known thyroid dysfunction

- Patients on medications that could affect thyroid functions e.g. Carbamazepine, Phenobarbitone, Phenytoin, Salicylates and Nonsteroidal anti-inflammatory drugs (NSAIDs)

- Patients with other etiology for liver cirrhosis e.g. history of significant alcohol consumption > 60 g/day, patients with positive HbsAg, patients with evidence of metabolic or autoimmune disease

- Patients under interferon therapy

- Patients admitted to the hospital in an acute event such as upper GI bleeding or sepsis.

- Patients with acute hepatitis and fulminant liver failure.

Patients were allocated to three groups

Group I: included 24 patients with compensated post-hepatitis C cirrhosis (Child's grade A)

Group II: included 24 Patients with decompensated post-hepatitis C cirrhosis (Child's grade B or C) without encephalopathy

Group III: included 24 Patients with decompensated post-hepatitis C cirrhosis (Child's grade B or C) with encephalopathy

All patients were subjected to:

- Thorough history taking regarding the duration of liver disease, history of alcohol intake

- Physical examination with special stress on manifestation of liver cirrhosis.

- Laboratory investigations including: Complete blood count (CBC) by Dyn 1700, Liver and kidney function tests including: Serum albumin, Total and direct bilirubin, Aspartate aminotransferase (AST), Alanine aminotransferase (ALT), serum creatinine and blood urea nitrogen by integra 400 analyser, coagulation profile, Prothrombin Time (PT) and (INR) by sysmex CA 1500, Serum antibodies to HCV and HbsAg by ELISA, auto immune markers (ANA, ALKM Ab, SMA) by slide immunoflorescence.

- Thyroid parameters including total T3, free T4 and TSH serum levels:

- T3 was measured using (Calbiotech, Inc. (CBI) total T3 ELISA kit). The assay was run fully automated. Normal level $=(0.52-1.58 \mathrm{ng} / \mathrm{ml})$.

- $\quad$ FT4 was measured using (Chemux BioScience, INC kit). The assay was run fully automated. Normal level = (0.65 - $1.97 \mathrm{ng} / \mathrm{dl})$.

- TSH test done using (Chemux BioScience, INC kit). The assay was run fully automated. Normal level $=(0.4$ $-7.0 \mathrm{uIU} / \mathrm{ml})$.

- Abdominal ultrasonography: examine patients for manifestations of liver cirrhosis and portal hypertension e.g. increased liver echogenicity, coarse echotexture, irregular borders, splenomegally, ascites, dilated portal vein.

- The severity of the liver dysfunction was graded according to Child-Pugh classification [12].

\begin{tabular}{|c|c|c|c|}
\hline & 1 & 2 & 3 \\
\hline Bilirubin Total & $<2 \mathrm{mg} / \mathrm{dl}$ & 2 - 3 mg/dl & $>3$ mg/dl \\
\hline Serum albumin & $>3.5 \mathrm{~g} / \mathrm{dl}$ & $2.8-3.5 \mathrm{~g} / \mathrm{dl}$ & $<2.8 \mathrm{~g} / \mathrm{dl}$ \\
\hline INR & $<1.7$ & $1.71-2.20$ & $>2.20$ \\
\hline Ascites & None & Suppressed with medication & Refractory \\
\hline Hepatic encephalopathy & None & $\begin{array}{l}\text { Grade I-II (or suppressed with } \\
\text { medication) }\end{array}$ & Grade III-IV (or refractory) \\
\hline \multicolumn{2}{|c|}{ Points } & \multicolumn{2}{|c|}{ Class } \\
\hline \multicolumn{2}{|c|}{$5-6$} & \multicolumn{2}{|c|}{ A } \\
\hline \multicolumn{2}{|c|}{$7-9$} & \multicolumn{2}{|c|}{ B } \\
\hline \multicolumn{2}{|c|}{$10-15$} & \multicolumn{2}{|c|}{$\mathrm{C}$} \\
\hline
\end{tabular}




\section{Statistical Analysis}

Data were analyzed using SPSS (Statistical Package for the Social Sciences) version 15 for data processing and statistics. Numbers and percentages were used for qualitative data while mean \pm standard deviation (SD) was used for quantitative ones. Chai square test $\mathrm{X}^{2}$ was used to compare categorical data and ANOVA was used to compare numerical data. KW test was used for numerical data when normal distribution is lacking. Linear regression was used to test the correlation between variables. $\mathrm{P}$ value $<0.05$ was considered significant.

\section{Results}

Comparison between the three studied groups as regards their demographic data shows that there were no significant differences as regards age and gender distribution as shown in Table 1. Table 2 represents comparison between the three studied groups as regards all the laboratory parameters. It shows that group I had significantly higher hemoglobin concentration, WBC's count and albumin concentration than the other two groups. Group I also had significantly lower bilirubin level, liver enzymes, PT, INR, urea and creatinine than the other two groups. When it comes to thyroid functions Table 2 shows that group I had significantly higher level of serum total T3 than the other two groups and group II had significantly higher level of serum total T3 than group III. Comparing the level of free T4 revealed no significant difference between the studied groups while the level of TSH was significantly higher in group II. Table 3 shows that most of the patients included in the study had normal thyroid function tests. Comparing the three studied groups as regards the prevalence of subnormal levels of the studied thyroid parameters shows that group III had statistically higher incidence of subnormal total T3 level than the other two groups and group II shows significantly higher incidence of subnormal total T3 than group I as shown in Table 3. Table 3 also shows that the prevalence of subnormal serum level of free T4 is not significantly different among the three groups. Also the level of TSH was within normal range in all patients of the three groups. Table 4 shows that there's highly significant negative correlation between total T3 and the Child's score while TSH has significant positive correlation with it.

\section{Discussion}

This work aims to study the relation between serum levels of some thyroid parameters specially total T3 and HCV related cirrhosis and their relation to the severity of decompensation. The three groups of patients in this study represented three degrees of hepatic decompensation to evaluate the relation between thyroid and liver functions. There were no significant differences between the three studied groups in this study as regard age and gender distribution.

There was a statistically significant difference between different studied groups regarding the mean value of serum total T3 and serum TSH. We found that, the mean value of serum total T3 was the lowest among decompensated cirrhotic patients with hepatic encephalopathy (group III) $(0.74 \pm 0.3 \mathrm{ng} / \mathrm{ml})$ and Kayacetin et al., 2003 agrees with this finding in is study on patients with hepatic encephalopathy, followed by decompensated cirrhotic patients without hepatic encephalopathy (group II) $(1.0 \pm 0.3 \mathrm{ng} / \mathrm{ml})$ but the highest mean value was seen among compensated cirrhotic patients (group I) $(1.33 \pm 0.3 \mathrm{ng} / \mathrm{ml})$ [13]. This means that mean level of total T3 in groups II and III was higher than in group I. These results come in agreement with most of the previous studies dealing with this topic (Yamanaka et al., 1980, Brozio et al., 1983, Shimada et al., 1988, Agha et al., 1989, Antonelli et al., 2006, Spadaro et al., 2004, Elkabbany et al., 2012, Mansour-Ghanaei et al., 2012 and Dehghani et al., 2013) [6] [14]-[21]. this finding is explained by the fact that liver plays a central role in the peripheral

Table 1. Demographic data.

\begin{tabular}{|c|c|c|c|c|c|c|c|c|c|c|}
\hline & & \multicolumn{2}{|c|}{$\begin{array}{l}\text { Group I } \\
\text { No }=24\end{array}$} & \multicolumn{2}{|c|}{$\begin{array}{c}\text { Group II } \\
\text { No }=24\end{array}$} & \multicolumn{2}{|c|}{$\begin{array}{c}\text { Group III } \\
\text { No }=24\end{array}$} & \multirow{2}{*}{$\begin{array}{c}\begin{array}{c}\text { Test } \\
\text { value }\end{array} \\
8.89^{*}\end{array}$} & \multirow{2}{*}{$\begin{array}{c}\mathbf{P} \\
<0.001\end{array}$} & \multirow{2}{*}{$\begin{array}{r}\text { Signif. } \\
\text { HS }\end{array}$} \\
\hline & & & 5.1 & & 8.1 & & 7.2 & & & \\
\hline \multirow{3}{*}{ Gender } & & No & $\%$ & No & $\%$ & No & $\%$ & & & \\
\hline & Male & 14 & 58.3 & 9 & 37.5 & 17 & 70.8 & $5.51^{\#}$ & 0.06 & NS \\
\hline & Female & 10 & 41.7 & 15 & 62.5 & 7 & 29.2 & & & \\
\hline
\end{tabular}


Table 2. Comparison between the three groups as regards all laboratory parameters.

\begin{tabular}{|c|c|c|c|c|c|c|}
\hline & $\begin{array}{l}\text { Group I } \\
\text { No }=24\end{array}$ & $\begin{array}{c}\text { Group II } \\
\text { No }=24\end{array}$ & $\begin{array}{c}\text { Group III } \\
\text { No }=24\end{array}$ & $\mathbf{F}$ & $\mathbf{P}$ & Signif. \\
\hline $\begin{array}{c}\mathrm{HB}(\mathrm{g} / \mathrm{dl}) \\
\text { Mean } \pm \mathrm{SD}\end{array}$ & $12.1 \pm 2.0$ & $10.1 \pm 2.4$ & $11.1 \pm 2.2$ & 4.9 & 0.009 & $\mathrm{~S}$ \\
\hline $\begin{array}{c}\left.\text { WBC's(cells } x^{3} 0^{3} / \mathrm{ml}\right) \\
\text { Mean } \pm \text { SD }\end{array}$ & $6.1 \pm 2.1$ & $7.1 \pm 3.5$ & $9.9 \pm 5.8$ & 5.29 & 0.007 & $\mathrm{~S}$ \\
\hline $\begin{array}{l}\left.\text { Platelet(cellsx10 }{ }^{3} / \mathrm{ml}\right) \\
\text { Mean } \pm \text { SD }\end{array}$ & $94.6 \pm 28.2$ & $91.3 \pm 30$ & $110.3 \pm 38.9$ & 2.3 & 0.1 & NS \\
\hline $\begin{array}{c}\text { Total Bilirubin (mg/dl) } \\
\text { Mean } \pm \text { SD }\end{array}$ & $0.9 \pm 0.4$ & $2.6 \pm 1.4$ & $3.7 \pm 2.5$ & 16.7 & $<0.001$ & HS \\
\hline $\begin{array}{c}\text { Direct Bilirubin(mg/dl) } \\
\text { Mean } \pm \text { SD }\end{array}$ & $0.3 \pm 0.2$ & $1.1 \pm 0.8$ & $1.8 \pm 1.5$ & 12.5 & $<0.001$ & HS \\
\hline $\begin{array}{l}\text { Albumin (g/dl) } \\
\text { Mean } \pm \text { SD }\end{array}$ & $3.6 \pm 0.5$ & $2.4 \pm 0.3$ & $2.5 \pm 0.5$ & 53.2 & $<0.001$ & HS \\
\hline $\begin{array}{c}\operatorname{ALT}(\mathrm{IU} / \mathrm{ml}) \\
\text { Mean } \pm \text { SD }\end{array}$ & $47.8 \pm 32.5$ & $46.2 \pm 28.3$ & $80.4 \pm 126$ & $\mathrm{KW}=1.16$ & 0.55 & NS \\
\hline $\begin{array}{l}\text { AST(IU/ml) } \\
\text { Mean } \pm \text { SD }\end{array}$ & $51.4 \pm 25.4$ & $63 \pm 45.9$ & $131.7 \pm 214.7$ & $\mathrm{KW}=5.2$ & 0.07 & NS \\
\hline $\begin{array}{c}\text { INR } \\
\text { Mean } \pm \text { SD }\end{array}$ & $1.16 \pm 0.14$ & $1.7 \pm 0.5$ & $1.6 \pm 0.4$ & 12.3 & $<0.001$ & HS \\
\hline $\begin{array}{c}\text { PT(sec) } \\
\text { Mean } \pm \text { SD }\end{array}$ & $13.5 \pm 0.7$ & $16.3 \pm 3.8$ & $16.1 \pm 2.7$ & 7.68 & $<0.001$ & HS \\
\hline $\begin{array}{l}\text { Blood Urea }(\mathrm{mg} / \mathrm{dl}) \\
\text { Mean } \pm \text { SD }\end{array}$ & $33.8 \pm 17.6$ & $59.9 \pm 43.8$ & $102 \pm 37.1$ & 11.2 & $<0.001$ & HS \\
\hline $\begin{array}{l}\text { Creatinine (mg/dl) } \\
\text { Mean } \pm \text { SD }\end{array}$ & $0.8 \pm 0.2$ & $1.1 \pm 0.6$ & $1.6 \pm 1.2$ & 5.6 & 0.005 & S \\
\hline $\begin{array}{c}\text { Child's Score(Points) } \\
\text { Mean } \pm \text { SD }\end{array}$ & $5.4 \pm 0.5$ & $10.2 \pm 1.5$ & $11.2 \pm 2.1$ & 99.03 & $<0.001$ & HS \\
\hline $\begin{array}{l}\text { Total T3(ng/ml) } \\
\text { Mean } \pm \text { SD }\end{array}$ & $1.33 \pm 0.3$ & $1.0 \pm 0.3$ & $0.74 \pm 0.3$ & 19.56 & $<0.001$ & HS \\
\hline $\begin{array}{l}\text { Free T4(ng/dl) } \\
\text { Mean } \pm \text { SD }\end{array}$ & $1.46 \pm 0.5$ & $1.47 \pm 0.8$ & $1.69 \pm 1.1$ & 0.56 & 0.58 & NS \\
\hline $\begin{array}{c}\text { TSH }(\mathrm{uIU} / \mathrm{ml}) \\
\text { Mean } \pm \text { SD }\end{array}$ & $0.86 \pm 0.57$ & $1.36 \pm 1.0$ & $0.81 \pm 0.6$ & $\mathrm{KW}=6.5$ & 0.03 & $\mathrm{~S}$ \\
\hline
\end{tabular}

Table 3. Comparison between the studied groups as regards the prevalence of hypothyroidism.

\begin{tabular}{|c|c|c|c|c|c|c|c|}
\hline & & $\begin{array}{c}<\text { Lower Limit } \\
\text { N = 72(\%) }\end{array}$ & $\begin{array}{c}\text { Normal Range } \\
\quad \mathrm{N}=72(\%)\end{array}$ & \multicolumn{2}{|c|}{$\begin{array}{c}\text { > Upper Limit } \\
\text { N = 72(\%) }\end{array}$} & & \\
\hline & Total T3 & 14 (19.4\%) & 57 (79.2\%) & \multicolumn{2}{|c|}{$1(1.4 \%)$} & & \\
\hline & Free T4 & 10 (13.9\%) & 56 (77.8\%) & \multicolumn{2}{|c|}{$6(8.3 \%)$} & & \\
\hline & TSH & $8(11.1 \%)$ & 64 (88.9\%) & \multicolumn{2}{|c|}{$0(0.0 \%)$} & & \\
\hline & & $\begin{array}{l}\text { Group I } \\
\text { No }=24\end{array}$ & $\begin{array}{c}\text { Group II } \\
\text { No }=24\end{array}$ & $\begin{array}{c}\text { Group III } \\
\text { No }=24\end{array}$ & $X^{2}$ & $\mathbf{P}$ & Signif. \\
\hline \multirow[t]{2}{*}{ Total T3 } & $\begin{array}{c}\text { Normal } \\
0.52-1.58 \mathrm{ng} / \mathrm{ml}\end{array}$ & 24 (100\%) & 20 (83.3\%) & 14 (58.3\%) & \multirow[t]{2}{*}{13.48} & \multirow[t]{2}{*}{0.001} & \multirow[t]{2}{*}{ HS } \\
\hline & $<$ Lower Limit & $0(0 \%)$ & $4(16.7 \%)$ & $10(41.7 \%)$ & & & \\
\hline \multirow[t]{2}{*}{ Free T4 } & $\begin{array}{c}\text { Normal } \\
0.65-1.97 \mathrm{ng} / \mathrm{dl}\end{array}$ & 22 (91.7\%) & 19 (79.2\%) & 21 (87.5\%) & \multirow[t]{2}{*}{1.63} & \multirow[t]{2}{*}{0.4} & \multirow[t]{2}{*}{ NS } \\
\hline & $<$ Lower Limit & 2 (8.3\%) & $5(20.8 \%)$ & 3 (12.5\%) & & & \\
\hline \multirow{2}{*}{ TSH } & $\begin{array}{c}\text { Normal } \\
0.4-7.0 \mathrm{uIU} / \mathrm{ml}\end{array}$ & $24(100 \%)$ & 24 (100\%) & 24 (100\%) & \multirow[t]{2}{*}{0.0} & \multirow[t]{2}{*}{1} & \multirow[t]{2}{*}{ NS } \\
\hline & >Upper Limit & $0(0 \%)$ & $0(0 \%)$ & $0(0 \%)$ & & & \\
\hline
\end{tabular}


Table 4. Correlation between thyroid function tests and Child's score.

\begin{tabular}{cccc}
\hline & R & P & Signif. \\
\hline Total T3 & -0.64 & $<0.001$ & HS \\
Free T4 & 0.15 & $>0.05$ & NS \\
TSH & 0.25 & $<0.05$ & S \\
\hline
\end{tabular}

conversion of T4 to T3 and that in conditions of liver cirrhosis the enzyme system of the diseased liver converts T4 to reverse T3b which is less active than T3 [8]. This finding was also explained by Novis et al., 2001 that found that the lower T3 level was accompanied by a higher reverse T3 level which is a less active form of the hormone that appear due to peripheral conversion of T4 [22]. This finding is also emphasized by Tas et al., 2012 in a study that linked this lower T3 levels to higher mortality in critically ill cirrhotic patients [23]. The level of free T4 showed no significant differences between the three groups, this agrees with Spadaro et al, 2004 and Elkabbany et al., 2012 [19] [20]. This finding disagrees with Yamanaka et al., 1980, Shimada et al., 1988, Agha et al., 1989, Kayacetin et al., 2003, Antonelli et al., 2006 and Dehghani et al., 2013 who said that the level of F T4 was also lower than non-cirrhotic patients [13] [14] [16]-[18] [21]. This also disagrees with Brozio et al., 1983 who found that free T4 was higher than non-cirrhotic patients [15]. The authors who say that the free T4 is lower in cirrhotic patients though they are clinically euthyroid explain this by the fact that there are some changes in the thyroid gland itself [19]. Comparing the three studied groups as regards TSH level revealed that group II had significantly higher TSH, this agrees with Aizawa et al., 1980, Schlienger et al., 1980 and Antonelli et al., 2006 [18] [24] [25]. This finding agrees also with Atalav et al., 2015 that said that cirrhotic patients have lower levels of TSH especially at night [26]. This finding disagrees with Spadaro et al., 2004 and Elkabbany et al., 2012 that found that there was no change in TSH level [19] [20].

A highly significant negative correlation was observed, between total T3 and Child's score and a significant positive correlation between TSH and Child's score and non significant correlation as regard serum free T4. This relatively comes in the same line with Mansour-Ghanaei et al. (2012) who found that only for serum total T3, its level decreased with advancing Child-Pugh score [6].

Comparing the three groups as regards prevalence of subnormal thyroid function levels, we found that the incidence of low serum total T3 (below the lower limit) was the highest in decompensated cirrhotic patients with hepatic encephalopathy (group III) (41.7\%), followed by decompensated cirrhotic patients without hepatic encephalopathy (group II) (16.7\%) versus none of the compensated cirrhotic patients (group I). This difference was statistically highly significant when compare compensated group I with other two decompensated groups (II, III), which means, in other words that the frequency of patients with serum total T3 level below the lower limit significantly increased with severity of liver cirrhosis. This finding agrees with Tas et al., 2012 who found that T3 level is correlated to MELD and Child's score of the patients. As regard serum FT4 level, in our study, we found that, There is no statistically significant correlation with the Child's score this also agrees with Tas et al., 2012. The study by Tas et al. disagrees with our study as regards the fact that the level of TSH is also correlated to the Child's score. Tas et al. believe that TSH isn't significantly correlated to the severity of liver disease [23].

In our study, it was found that $11.1 \%$ (8 patients) of all patients with liver cirrhosis had serum TSH level below the lower limit, serum TSH level was normal in most cases. With a closer look at these abnormalities, patients with low serum TSH level included 3 patients with compensated liver cirrhosis (group I) and 5 patients with decompensated liver cirrhosis with hepatic encephalopathy (group III). This can be explained by the fact that late alteration in thyroid metabolism is a decrease in the pituitary secretion of TSH. Such changes may be a self-protective adaptation to illness, as the body attempts to conserve energy [27].

Such thyroid function derangements sought in this study may be attributed either to a true thyroid dysfunction associated with liver disease or the well-established entity of non-thyroidal illness syndrome (NTIS) formerly known as sick euthyroid syndrome. These findings agree with previous studies that analyzed thyroid dysfunction during critical illness as Fliers et al. study that reported a significant inverse correlation between serum total T3 concentrations and the severity of liver dysfunction. Also, Borzio et al. study that compared cirrhotic with normal subjects and chronic hepatitis patients. They found that serum total and free T3 levels inversely paralleled severity of liver dysfunction. TSH levels are described to be commonly within the normal range in NTIS but may decrease in prolonged illness [15] [28]. 


\section{Conclusion}

Patients with chronic liver disease may have lower serum total T3 level than normal though clinically euthyroid. The decline in thyroid function is correlated to the severity of liver disease.

\section{Conflict of Interests}

The research was conducted in the absence of any commercial or financial relationships that could be construed as a potential conflict of interest.

\section{References}

[1] Iredale, J.P. (2003) Cirrhosis: New Research Provides a Basis for Rational and Targeted Treatments. BMJ, 327, 143147. http://dx.doi.org/10.1136/bmj.327.7407.143

[2] Puche, J.E., Saiman, Y. and Friedman, S.L. (2013) Hepatic Stellate Cells and Liver Fibrosis. Comprehensive Physiology, 3, 1473-1492. http://dx.doi.org/10.1002/cphy.c120035

[3] Hennemann, G., Docter, R., Friesema, E.C., de Jong, M., Krenning, E.P. and Visser, T.J. (2001) Plasma Membrane Transport of Thyroid Hormones and Its Role in Thyroid Hormone Metabolism and Bioavailability. Endocrine Reviews, 22, 451-476. http://dx.doi.org/10.1210/edrv.22.4.0435

[4] Mendel, C.M., Cavalieri, R.R. and Weisiger, R.A. (1988) Uptake of Thyroxine by the Perfused Rat Liver: Implications for the Free Hormone Hypothesis. The American Journal of Physiology, 255, E110-E119.

[5] Bianco, A.C., Salvatore, D., Gereben, B., Berry, M.J. and Larsen, P.R. (2002) Biochemistry, Cellular and Molecular Biology, and Physiological Roles of the Iodothyronine Selenodeiodinases. Endocrine Reviews, 23, 38-89. http://dx.doi.org/10.1210/edrv.23.1.0455

[6] Mansour-Ghanaei, F., Mehrdad, M., Mortazavi, S., Joukar, F., Khak, M. and Atrkar-Roushan, Z. (2012) Decreased Serum Total T3 Level in Hepatitis B and C Related Cirrhosis by Severity of Liver Damage. Annals of Hepatology, 11, 667-671.

[7] Bianchi, G.P., Zoli, M., Marchesini, G., Volta, U., Vecchi, F., Iervese, T., Bonazzi, C. and Pisi, E. (1991) Thyroid Gland Size and Function in Patients with Cirrhosis of the Liver. Liver, 11, 71-77. http://dx.doi.org/10.1111/j.1600-0676.1991.tb00495.x

[8] Malik, R. and Hodgson, H. (2002) The Relationship between the Thyroid Gland and the Liver. QJM, 95, 559-569. http://dx.doi.org/10.1093/qjmed/95.9.559

[9] Oren, R., Sikuler, E., Wong, F., Blendis, L.M. and Halpern, Z. (2000) The Effects of Hypothyroidism on Liver Status of Cirrhotic Patients. Journal of Clinical Gastroenterology, 31, 162-163. http://dx.doi.org/10.1097/00004836-200009000-00016

[10] Oren, R., Brill, S., Dotan, I. and Halpern, Z. (1998) Liver Function in Cirrhotic Patients in the Euthyroid versus the Hypothyroid State. Journal of Clinical Gastroenterology, 27, 339-341. http://dx.doi.org/10.1097/00004836-199812000-00012

[11] Mohamed, M.K. (2005) Epidemiology of HCV in Egypt. The Afro-Arab Liver Journal, 3, 41-52.

[12] Child, C.G. and Turcotte, J.G. (1964) Surgery and Portal Hypertension. In: Child. C.G., Ed., The Liver and Portal Hypertension, Saunders, Philadelphia, 50-64.

[13] Kayacetin, E., Kisakol, G. and Kaya, A. (2003) Low Serum Total Thyroxine and Free Triiodothyronine in Patients with Hepatic Encephalopathy Due to Non-Alcoholic Cirrhosis. Swiss Medical Weekly, 133, 210-213.

[14] Yamanaka, T., Ido, K., Kimura, K. and Saito, T. (1980) Serum Levels of Thyroid Hormones in Liver Diseases. Clinica Chimica Acta, 101, 45-55.

[15] Borzio, M., Caldara, R., Borzio, F., Piepoli, V., Rampini, P. and Ferrari, C. (1983) Thyroid Function Tests in Chronic Liver Disease: Evidence for Multiple Abnormalities Despite Clinical Euthyroidism. Gut, 24, 631-636. http://dx.doi.org/10.1136/gut.24.7.631

[16] Shimada, T., Higashi, K., Umeda, T. and Sato, T. (1988) Thyroid Functions in Patients with Various Chronic Liver Diseases. Endocrinologia Japonica, 35, 357-369. http://dx.doi.org/10.1507/endocri1954.35.357

[17] Agha, F., Qureshi, H. and Khan, R.A. (1989) Serum Thyroid Hormone Levels in Liver Cirrhosis. Journal of Pakistan Medical Association, 39, 179-183.

[18] Antonelli, A., Ferri, C., Fallahi, P., Ferrari, S.M., Ghinoi, A., Rotondi, M. and Ferrannini, E. (2006) Thyroid Disorders in Chronic Hepatitis C. The American Journal of Medicine, 117, 10-13. 
[19] Spadaro, L., Bolognesi, M., Pierobon, A., Bombonato, G., Gatta, A. and Sacerdoti, D. (2004) Alterations in Thyroid Doppler Arterial Resistance Indices, Volume and Hormones in Cirrhosis: Relationships with Splanchnic Haemodynamics. Ultrasound in Medicine and Biology, 30, 19-25. http://dx.doi.org/10.1016/j.ultrasmedbio.2003.10.008

[20] El-Kabbany, Z.A., Hamza, R.T., Abd El Hakim, A.S. and Tawfik, L.M. (2012) Thyroid and Hepatic Haemodynamic Alterations among Egyptian Children with Liver Cirrhosis. ISRN Gastroenterol, 2012, 595734. http://dx.doi.org/10.5402/2012/595734

[21] Dehghani, S.M., Haghighat, M., Eghbali, F., Karamifar, H., Malekpour, A., Imanieh, M.H. and Malek-Hoseini, S.A. (2013) Thyroid Hormone Levels in Children with Liver Cirrhosis Awaiting a Liver Transplant. Experimental and Clinical Transplantation, 11, 150-153. http://dx.doi.org/10.6002/ect.2012.0182

[22] Novis, M., Vaisman, M. and Coelho, H.S. (2001) Thyroid Function Tests in Viral Chronic Hepatitis. Arquivos De Gastroenterologia, 38, 254-260.

[23] Taş, A., Köklü, S., Beyazit, Y., Kurt, M., Sayilir, A., Yeşil, Y. and Çelik, H. (2012) Thyroid Hormone Levels Predict Mortality in Intensive Care Patients with Cirrhosis. The American Journal of the Medical Sciences, 344, 175-179. http://dx.doi.org/10.1097/MAJ.0b013e318239a666

[24] Aizawa, T., Yamada, T., Tawata, M., Shimizu, T., Furuta, S., Kiyosawa, K. and Yakata, M. (1980) Thyroid Hormone Metabolism in Patients with Liver Cirrhosis, as Judged by Urinary Excretion of Triiodothyronine. Journal of the American Geriatrics Society, 28, 485-491. http://dx.doi.org/10.1111/j.1532-5415.1980.tb01126.X

[25] Schlienger, J.L., Jacques, C., Sapin, R. and Stephan, F. (1980) Thyroid Function in Patients with Alcoholic Cirrhosis. Ann Endocrinol (Paris), 41, 81-94.

[26] Atalay, R., Ersoy, R., Demirezer, A.B., Akın, F.E., Polat, S.B., Cakir, B. and Ersoy, O. (2015) Day-Night Variations in Thyroid Stimulating Hormone and Its Relation with Clinical Status and Metabolic Parameters in Patients with Cirrhosis of the Liver. Endocrine, 48, 942-948. http://dx.doi.org/10.1007/s12020-014-0364-1

[27] Hamblin, P.S., Dyer, S.A., Mohr, V.S., Le Grand, B.A., Lim, C.F., Tuxen, D.V., Topliss, D.J. and Stockigt, J.R. (1986) Relationship between Thyrotropin and Thyroxine Changes during Recovery from Severe Hypothyroxinemia of Critical Illness. The Journal of Clinical Endocrinology \& Metabolism, 62, 717-722. http://dx.doi.org/10.1210/jcem-62-4-717

[28] Fliers, E., Bianco, A.C., Langouche, L. and Boelen, A. (2015) Thyroid Function in Critically Ill Patients. The Lancet Diabetes \& Endocrinology, 3, 816-825. http://dx.doi.org/10.1016/S2213-8587(15)00225-9 